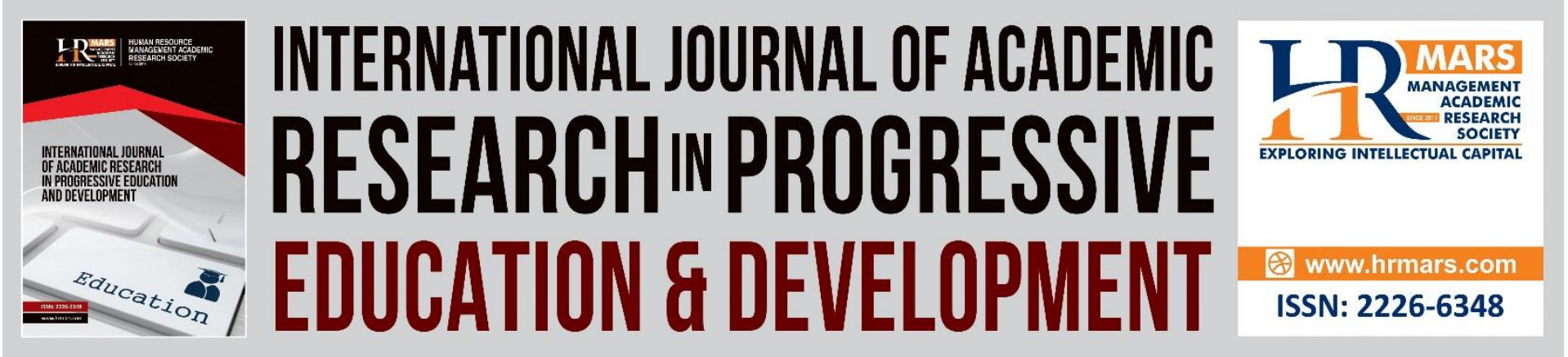

\title{
Learning Styles of English as a Second Language (ESL) Upper Primary School Students
}

\author{
Dhaayaaliny Pasupathy, Parilah Mohd Shah
}

To Link this Article: http://dx.doi.org/10.6007/IJARPED/v10-i3/10588

DOI:10.6007/IJARPED/v10-i3/10588

Received: 06 June 2021, Revised: 10 July 2021, Accepted: 29 July 2021

Published Online: 23 August 2021

In-Text Citation: (Pasupathy \& Shah, 2021)

To Cite this Article: Pasupathy, D., \& Shah, P. M. (2021). Learning Styles of English as a Second Language (ESL) Upper Primary School Students. International Journal of Academic Research in Progressive Education and Development, 10(3), 629-649.

Copyright: (C) 2021 The Author(s)

Published by Human Resource Management Academic Research Society (www.hrmars.com)

This article is published under the Creative Commons Attribution (CC BY 4.0) license. Anyone may reproduce, distribute, translate and create derivative works of this article (for both commercial and non-commercial purposes), subject to full attribution to the original publication and authors. The full terms of this license may be seen at: http://creativecommons.org/licences/by/4.0/legalcode

Vol. 10(3) 2021, Pg. 629 - 649

http://hrmars.com/index.php/pages/detail/IJARPED

JOURNAL HOMEPAGE

Full Terms \& Conditions of access and use can be found at http://hrmars.com/index.php/pages/detail/publication-ethics 


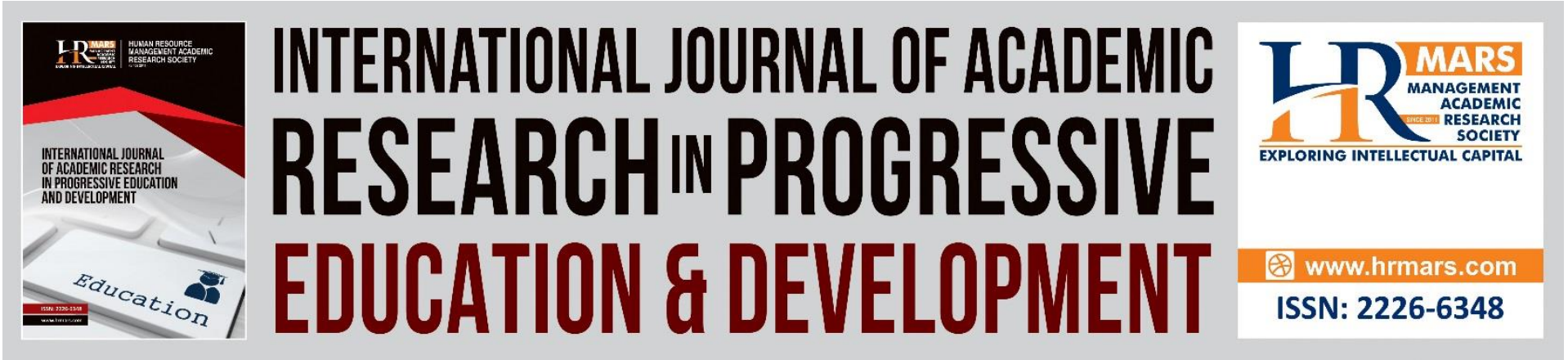

\title{
Learning Styles of English as a Second Language (ESL) Upper Primary School Students
}

\author{
Dhaayaaliny Pasupathy, Parilah Mohd Shah \\ SJKC Tanah Merah Site C, Universiti Kebangsaan Malaysia
}

\begin{abstract}
People in general have different ways and methods of perceiving, processing and dissecting information thus leading to learners practising a certain learning style. The chosen learning style allows individual to acquire and process knowledge in any subjects taught in schools specifically among students who learn English as a Second Language. The purpose of this research is to investigate the most common learning styles of English as a Second Language (ESL) upper primary school students. The sample consisted of 30 students from Year 4,5, and 6 from one of the Sekolah Jenis Kebangsaan Cina (SJKC)s in Port Dickson district. This research utilizes the quantitative approach to determine the pattern of learning styles of the ESL upper primary school students. Felder-Silverman Learning Style Model (FSLSM) has been adopted in supporting this research. The items for this research's questionnaire has been adopted and adapted from FSLSM to collect data on the students' learning style preference because it has been used widely in the field of learning styles and also due to its credibility and suitability to this research. The questionnaire consists of two parts; Section A with 2 items and Section B with 44 items. The items substantiating 4 dimensions and 4 sub-scales, that is to say perception (sensing / intuitive learners), procession (active / reflective learners), input (visual / verbal learners) and comprehension (sequential / global learners). Every dimension comprises of 11 items. The questionnaire set was distributed to 30 upper primary. The data was analysed using the Statistical Package for Social Sciences (SPSS) software version 20 where descriptive analysis was used to analyse frequency. Results from the analysis showed that in whole, the ESL upper primary school students of this SJKC are more dominant in visual $(80 \%)$ than verbal style (20\%) for input dimension; followed by sequent $(76.7 \%)$ than global style $(23.3 \%)$ for comprehension dimension; active $(56.7 \%)$ than reflective style $(43.3 \%)$ for procession dimension and intuitive $(60 \%)$ than sensing style(40\%) for perception dimension. The findings of this research, the research suggests that educator should pay more attention in selecting and employing the most apt teaching method to cater the learning styles that have been reported.
\end{abstract}

Keywords: ESL, Learning Styles, Felder-Silverman Learning Style Model (FSLSM)

\section{Introduction}

Learning usually is influenced by the various ways or methods that one chooses to learn. These methods or styles are normally developed by an individual due to his or her unique 
characteristcs. A continuous process of gaining knowledge and skills are said to be the essence of learning as defined by Tony Bingham and Marcia Conner (2010). Learning style refers to individuals' preferences in learning. Many experts have different definitions of learning style. According to Pashler, McDaniel, Rohrer \& Bjork (2008), "learning styles" refers to the concept that individuals differ pertaining to what manner of instruction or research is most effective for them. Sangeeth (2014) stated that the three most common learning styles used by Malaysian students are visual, auditory and kinaesthetic. Individuals, in language learning might have their own preferred learning style preferences due to certain factors, such as personal characteristics, as well as ethnic, cultural and educational background (Kang 1999). It is vital to identify the most preferred learning styles, failing to do so may affect the students' academic development as Felder \& Silverman (1988) pointed out that students with a strong preference for a specific learning style may have difficulties if the teaching style does not match their preferred learning styles. Simon Cassidy \& Peter Eachus (2000) stated that students who have learning styles corresponding well to the educators' teaching styles have high tendency of retaing the learnt knowledge for a longer time. In accordance to this requirement, the purpose of this research was to identify the most prefered learning styles of the ESL upper primary school students using the Felder-Silverman learning style model (FSLSM).

\section{Rationale of the Research}

According to Kang (1999), in language learning, a person may opt to having her or his individualistic learning style, affected by a few factors such as cultural, educational and ethnic background, added by the person's distinctive characteristics. Learning styles are heavily incorporated to intensify the teaching and learning whereby a lot of research work has been conducted in terms of learning of ESL as mentioned by Putintseva (2006) where an assortment of approaches to learning styles as been indicated to emphasize the importance of learning style in ESL when the teaching and learning of ESL is concerned. This research was carried out to give an overview on the learning styles of ESL Upper Primary School students by figuring out their pattern of learning styles and the findings of this research are hoped to be provide benefits to educators especially English teachers in choosing and carrying out the most appropriate teaching methods and learning activities to cater the students' learning styles, ensuring the students reach the maximum level of academic development especially in English accordingly.

\section{Problem Statement}

Students' preferred learning style is very essential in ensuring intellectual development happens especially one concerning ESL students in primary schools in Malaysia. Effective learning can only occur when the students have the right methods or strategies to encourage intellectual development. students. Bjork (2008) stated that students have a dificult time in trying to achieve good grades in subjects like English because their needs are not met because teachers are not able to conduct lessons catering to the students' respective learning styles. Focusing on the low achievements on academic subjects especially in English among the ESL upper primary school students, the researcher decided to investigate the students' learning styles that will be utilised to aid educators in selecting and using the most appropriate teaching strategies to cater to every student's learning style. 
INTERNATIONAL JOURNAL OF ACADEMIC RESEARCH IN PROGRESSIVE EDUCATION AND

DEVELOPMENT

Vol. 10, No. 3, 2021, E-ISSN: 2226-6348 ㄷ 2021 HRMARS

\section{Research Questions}

This research intends to answer the following core question:-

1. What are the learning styles of ESL Upper Primary School students?

\section{Literature Review \\ Theoretical Framework}

The theoretical scope that supports this research involves various definitions of learning styles theories and one chosen learning style model

\section{Learning Style Definitions}

A person's distinctive way of perceiving and processing a piece or information is widely known as learning style. Mok (2003) specifies learning style as learning conceptualization as chosen by the students and Jantan \& Razali (2002) stated that learning style is the manner in which the students concentrate and their personalised way of processing and obtaining knowledge,information or experience. Meanwhile, Drago \& Wagner (2004) defines learning style as differences that subsist between a person over every learning approach. Moreover, learning style is seen as assorted methods in perceiving, processing and creating information to develop concepts and principles as defined by Fleming \& Baume (2006). Yaakub and Hashim (2004), on the other hand, view learning style as an activity involving mental, physical and spiritual aspects. it is a process that constantly brings changes in an individual's behaviours in a consistent and continuous manner which allows the individual to utilise the perceived knowledge and skills to progress successfully. They also reckon learning style as a way for an individual to maximize and utilize his or her capability. Other than the mentioned definitions, there are assorted existing definitions that come from different perspectives of researches such as experiential learning by Kolb (1984), psychological and environmental aspects by Dunn \& Dunn (1978), modality by Dunn (1981), personality brain hemisphere mastery by McCarthy (1982). Though there is no one specific source dating back to the origin of the term learning style as mentioned by $\mathrm{Wu}$ (2014) who further elaborated that there are conflicting chronicle concerning the origin of learning style, Fazarro et al (2009) claimed that Thelen (1954) was the first researcher to have used the term 'learning style' in giving description of people learning and interacting in a particular environment. Though such claim had been made, the interest shown by a few researchers such as Gregorc (1982); Dunn and Dunn (1978); McCarthy (1982); Kolb (1979) and Keefe (1979), as cited in Thronson (1984) has been said to be the cause behind the real spread of the term which has been widely popularised.

\section{Related Learning Styles Theories}

According to Thronson (1984), there are two branches of renewed attempts in popularising learning styles; applied models of learning style and strong preference for the cognitive style dimension. Based on this, in this research, three majorly used theories and models will be compared to further explain the different view and aspects of learning styles 
Kolb's \& Visual, Aural, Read or Write and Kinesthetic (VARK)Learning Style Model

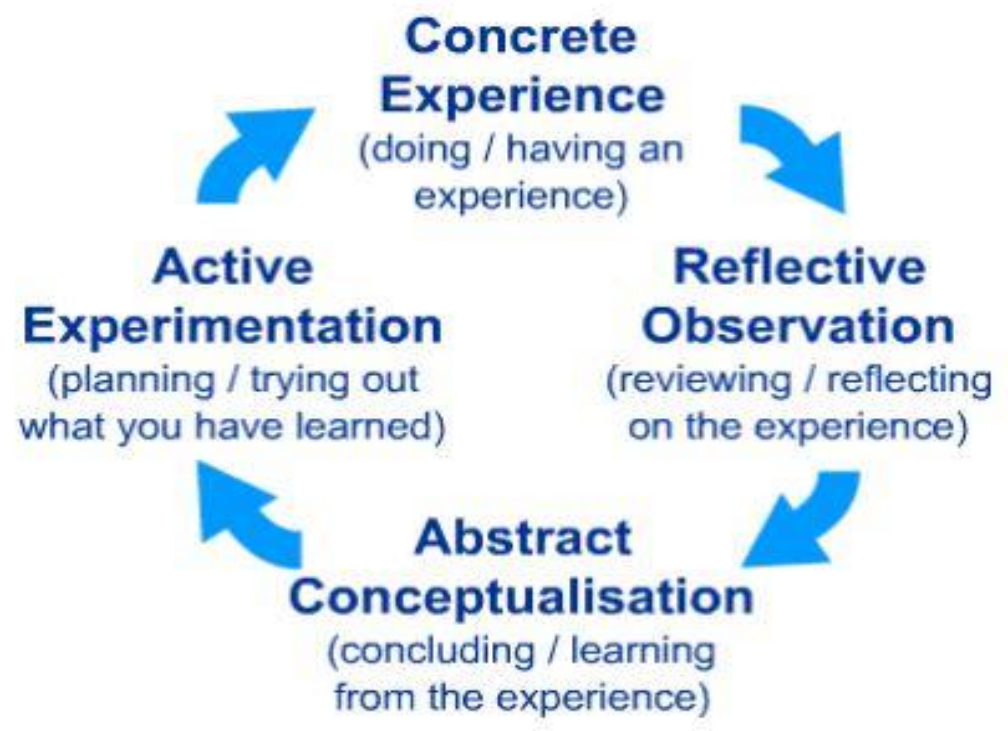

Figure 1 Kolb's Experiential Learning Cycle

Kolb's learning style theory (1974) lays down four clean-cut learning styles (Diverging, Assimilating, Converging and Accommodating), which are based on a four-stage learning cycle as shown in the figure above.

Kolb's Learning Theory, an individual's learning style preference is the product of two pairs of variables, or two separate choices that he or she makes in which Kolb laid out as lines of a mechanism, each with conflicting modes at both ends. Kolb strongly had faith in the concept where learners are not capable of performing both variables on a single axis at the same time like thinking and feeling at the same time, reemphasizing that. An individual's learning style is a product of these two choice decisions.

Moving on to VARK's Learning style, it emphasizes four learning modes that is to say; visual mode, aural mode, reading mode and kinesthetic mode. Students are expected to choose the most optimum learning style based on these modes. Each mode has identifiable characteristics that can be seen through the students who prefer it. 


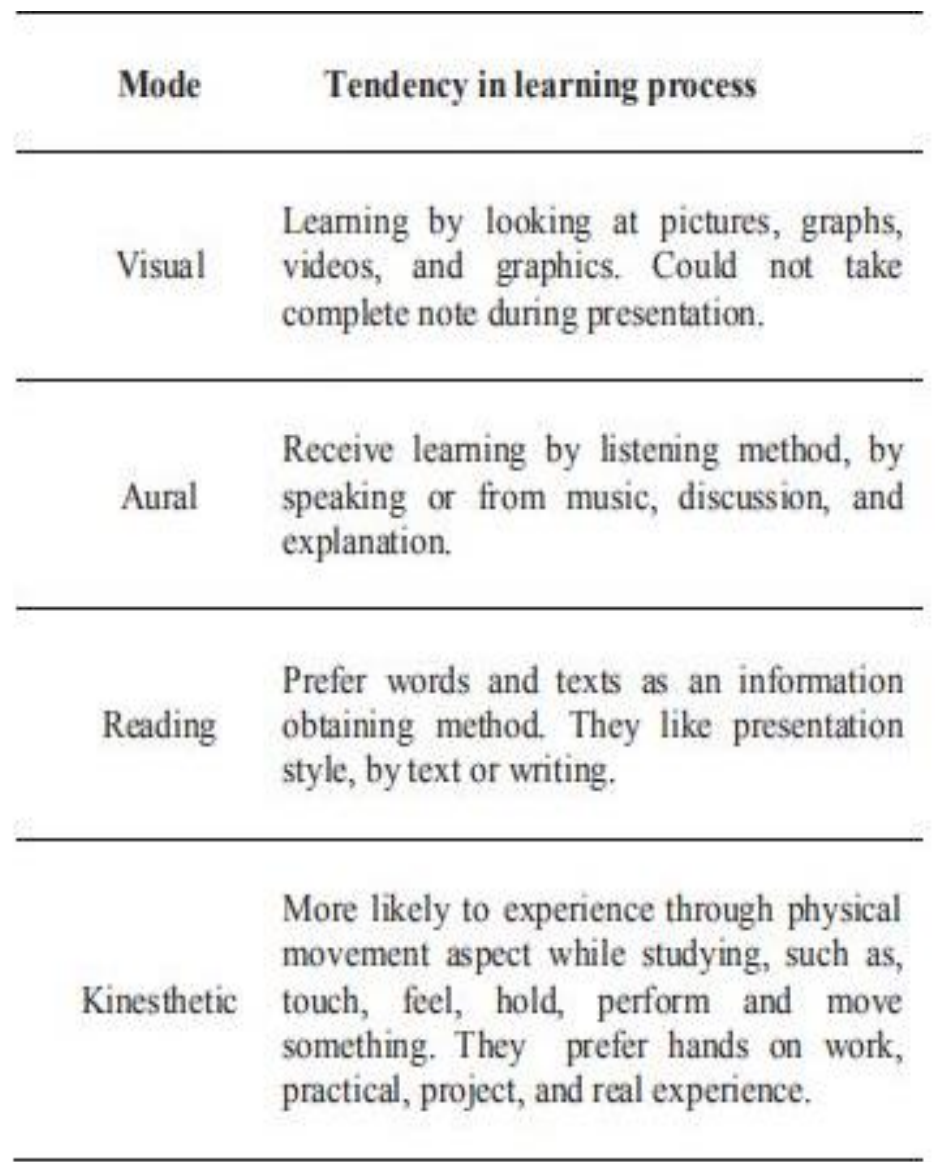

Figure 2 The tendency in learning process based on VARK mode

In short, VARK learning style model does not have any relevance to one's intelligence or innate skills as it slants heavily towards the manner in which learners acquire or comprehend information and new knowledge.

\section{The Chosen Theoretical Framework}

\section{Felder-Silverman Learning Style Model (FSLSM)}

Dissimilar from the two mentioned models above, Felder and Silverman's learning style model is a perfect mix of the modes and stages in other models. There are four dimensions in which students belonging to a particular end of one of the dimensions are said to learn differently compared to the ones who are slightly balanced in the other end of that dimension. The detailed explanation of each dimension has been stated by Felder (1993) and Felder \& Soloman (2006) in the respective researches. 


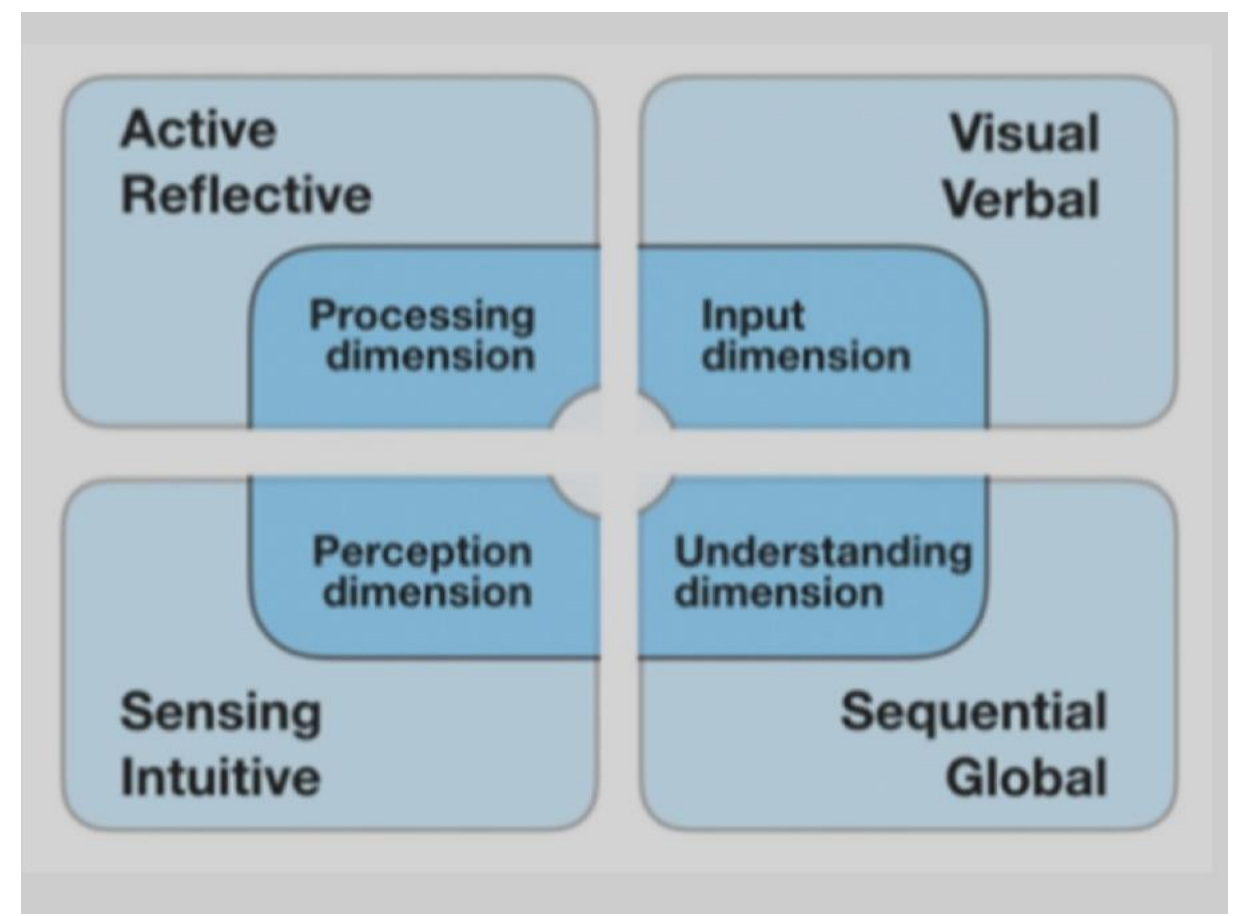

Figure 3 Felderman-Silvrman Learning Style Model

\section{Active \& Reflective Learners}

Based on this model, active learners are those who like hands-on activities in classroom and group activities which allow them to process information better. Active learners are also social-beings and love doing active things such as discussing, explaining to others and applying. Reflective learners, in converse prefer processing information in a silent environment on their own as this help them to go through every thought and idea in their mind in accordance to their pace. They are personal beings who learn alone by thinking things through and through. They would prefer thinking about something first before taking any action.

\section{Sensing \& Intuitive Learners}

This dimension focuses in the concrete versus abstract concepts. Sensing learners as those who have high preference in dealing with facts and real-world scenarios, relying heavily on proven methods and formulas to solve problems. They are careful individuals and learn better if the information is factual, or is given in such a way where they can see, touch and apply.Contradicting this, intuitive learners are more leaned towards originality and innovation, preferring ideas that are abstract and scenarios that are hypothetical. They are very unforbearing with details, do not like repetition and are more comfortable with mathematical formulations. They also always find innovative and new ways to solve existing and old problems.

\section{Visual \& Verbal Learners}

In this dimension, visuals learners are said to be individuals who love processing information using visual cues such as images, illustrations, diagrams and graphs. They prefer visual representation of the given materials because they would understand better when visual aids are used to present a certain piece of information,opposing to verbal learners who rely on 
words to gain and process information. They feel comfortable being in discussion of idea as they benefit more from it.These verbal learners learn better through words and explanations that are in written or spoken form.

\section{Sequential \& Global}

Sequential learners like learning in small additive steps which leads to them having a learning progress that is linear. They have the tendency of following the most logical ways to discover solutions. In the exact opposite axis, global learners employ a holistic way of thinking and learning in large steps. They would usually randomly absorb learning materials that they have without making any visible connections but once they have gone through the entire learning material, they would somehow comprehend the whole picture immediately. This leads to them having tendency of solving complex problems without paying much attention to the details, as long as they get the over-views.

In essence, FSLSM has been established based on tendencies, showing that learners with a high preference for certain behaviour can also act sometimes differently. This trait alone makes this model the perfect fit for this research as it allows the highest level of flexibility in determining the students' learning styles, not just limiting them to one mode or stage alone.

\section{Methodology \\ Research Design}

The research's data was obtained by conducting quantitative approach through questionnaire method. Creswell (1994) defined quantitative research as a type of research that is 'explaining phenomena by collecting numerical data that are analyzed using mathematically based methods (in particular statistics). MacDonald and Headlam (2014) also defined quantitative as a method that see population numerically where the researcher will quantify the data in percentage as a whole and those data will be analysed and interpreted statically. The questionnaire has been adopted from the Index of Learning Syles Questionnaire by Felder \& Solomon and the core of the research will be based on Felder-Silverman Learning Style Model (FSLSM) as the conceptual framework of the research.

\section{Research Sample}

For this research, stratified random sampling technique was used to produce and manage the questionnaire. The sampling were all Upper Primary(Year 4,5 \& 6 ) ESL students, in which 30 students were involved from one of the Sekolah Jenis Kebangsaan Cina (SJKC)s located in Port Dickson where the students come from various races like. Omair (2014) stated that in random sampling, researchers can employ stratified sampling as sampling procedure as it helps to distinguish the list by categories based on preset characteristics such as gender, age and number of years in learning English language. The results acquired from the respondents were utilised to identify the most common learning styles preffered by ESL upper primary school students.

\section{Research Instrument}

The Index of Learning Styles (ILS) questionnaire formulated by Felder and Soloman based on the Felder-Silverman Learning Style Model (FSLSM) was used in this research to determine to most prefered learning styles among ESL Upper Primary School students using the four dimensions of FSLSM. Chin, Lim, Mok, Saw, \& Tey (2017) described a good set of a 
questionnaire as simple and clean set where the steps or instructions to answer the questions must be specified at the top of the questions. This questionnaire has 44 items where the preferences of an individual for each dimension has been expressed with values between +11 to -11 per dimension, with steps $+/-2$. Felder and Spurlin (2005) explained that the given range comes from the 11 questions that are found in each dimension. If the students answer a question, for instance, with an sensing preference, +1 is added to the value of the sensing/intuitive dimension whereas an answer for a intuitive preference decreases the value by 1 . Graf, Viola, Leo, \& Kinshuk (2007) mentioned that every question answered will either be with a value of +1 (answer $\boldsymbol{a}$ ) or -1 (answer $\boldsymbol{b}$ ). Answer $\boldsymbol{a}$ corresponds to the preference for the first pole of each dimension (active, sensing, visual, or sequential), answer $\boldsymbol{b}$ to the second pole of each dimension (reflective, intuitive, verbal, or global). The questionnaire consists of two sections; Section A and Section B. Section A comprises the respondents' demographic data such as gender and age while Section B covers the respondents' preferred learning styles in the context of English language learning through 44 questions as shown below.

Index of Learning Styles Questionnaire

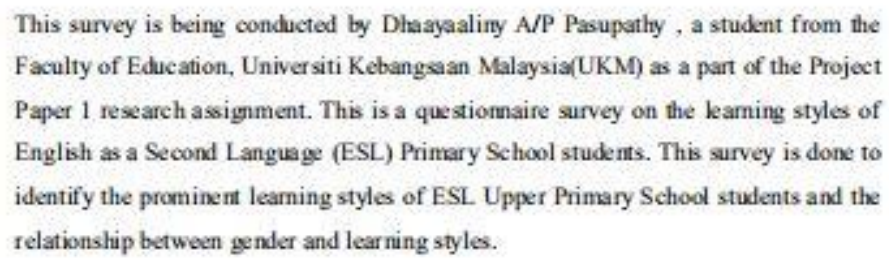

A: Background Information

Instruction: Tick the most suitable option.

1. Gender :

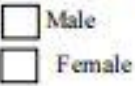

2. Age :

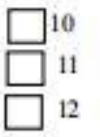

\section{B: Index of Learning Stviles}

Instruction : For each of the 44 questions below, select either " $A^{*}$ or ${ }^{7} \mathrm{~B}$ " to show your answer.

Please choose only ONE answer for each question.

If both "A" or "B" seem to apply to you, choose the one that applies more frequently. 
INTERNATIONAL JOURNAL OF ACADEMIC RESEARCH IN PROGRESSIVE EDUCATION AND DEVELOPMENT

Vol. 10, No. 3, 2021, E-ISSN: 2226-6348 @ 2021 HRMARS

1. I understand something better after I

(A) try it out.

(B) think it through.

2. I would rather be considered

(A) realistic.

(B) innovative.

3. When I think about what I did yesterday, I am most likely to get

(A) a picture.

(B) words.

4. I usually like to

(A) understand details of a subject but may understand less about its

overall structure.

(B) understand the overall structure but may be understand less about details.

5. When I am leaming something new, it helps me to

(A) talk about it.

(B) think about it.

6. If I were a teacher, I would choose to teach a course

(A) that deals with facts and real life situations.

(B) that deals with ideas and theories.

7. I prefer to get new information in

(A) pictures, diagrams, graphs, or maps.

(B) written directions or verbal information.

8. Once I understand

(A) all the parts, I understand the whole thing.

(B) the whole thing I see how the parts fit. 
INTERNATIONAL JOURNAL OF ACADEMIC RESEARCH IN PROGRESSIVE EDUCATION AND

DEVELOPMENT

Vol. 10, No. 3, 2021, E-ISSN: 2226-6348 @ 2021 HRMARS

9. In a study group working on diff icult manerial, I am more likely to

(A) jump in and give ideas.

(B) sit back and listen.

10. I find it easier

(A) to learn facts.

(B) to learn concepts.

11. In a book with lots of pictures and charts, I am like ly to

(A) look over the pictures and charts carefully.

(B) focus on the written text.

12. When I solve math problems

(A)I usually work my way to the solutions one step at a time.

(B) I often just see the solutions but then have to struggle to write the steps to get to

them.

13. In my ebss

(A) I have usually gotten to know many of the students.

(B) I have rarely gotten to know many of the students.

14. In reading non-fiction, I prefer

(A) something that teaches me new facts or tells me how wo do some thing.

(B) something that gives me new ideas to think about.

15. I like teachers

(A) who put a lot of diagrams on the board.

(B) who spend a lot of time explaining. 
INTERNATIONAL JOURNAL OF ACADEMIC RESEARCH IN PROGRESSIVE EDUCATION AND

DEVELOPMENT

Vol. 10, No. 3, 2021, E-ISSN: 2226-6348 @ 2021 HRMARS

16. When Im analyzing a story or a novel

(A) I think of the incidents and try to put them together wo figure out

the themes.

(B) I just know what the themes are when I finish reading and then

I have to go back and find the incidents that demonstr ate them.

17. When I start a homework problem, I am more likely to

(A) start working on the solution immediately.

(B) try to fully understand the problem first.

18. I prefer the idea of

(A) certainty.

(B) theory.

19. I remember best

(A) what I see.

(B) what I hear.

20. It is more important to me that the teacher

(A) lays out the material in clear sequential steps.

(B) gives me an overall picture and relate the material to other subjects.

21. I prefer to study

(A) in a study group.

(B) alone.

22. I am more likely to be considered

(A) careful about the details of my work. $\square$

(B) creative about how to do my work. 
INTERNATIONAL JOURNAL OF ACADEMIC RESEARCH IN PROGRESSIVE EDUCATION AND

DEVELOPMENT

Vol. 10, No. 3, 2021, E-ISSN: 2226-6348 @ 2021 HRMARS

23. When I get directions to a new place, I prefer

(A) a map.

(B) written instructions.

24. I learn

(A) at a fairly regular pace. If I study hard, III understand it.

(B) in fits and starts, III be totally conf used and then suddenly I'Il understand all.

25. I would rather first

(A) try things out.

(B) think about how Im going to do it.

26.When I am reading for enjoyment, 1 like writers to

(A) clearly say what they mean.

(b) say things in creative, interesting ways

27. When I see a diagram or sketch in class, I am most likely to remember

(A) the picture.

(B) what the teacher said about it.

28. When considering a body of information, I am more likely to

(A) focus on details and miss the big picture.

(B) try 10 understand the big picture before getting into the detaik.

29. I more easily remember

(A) something I have done.

(B) something I have thought a bot about.

30. When I have to performa task, I prefer to

(A) master one way of doing it.

(B) come up with new ways of doing it. 
INTERNATIONAL JOURNAL OF ACADEMIC RESEARCH IN PROGRESSIVE EDUCATION AND

DEVELOPMENT

Vol. 10, No. 3, 2021, E-ISSN: 2226-6348 @ 2021 HRMARS

31. When someone is showing me data, I prefer

(A) charts or graphs.

(B) text summarizing the result.

32. When writing an essay, I am more likely to

(A) work on (think about or write) the beginning of the essay and progress forward.

(B) work on (think about or write) different parts of the essay and then arrange them.

33. When I have wo work on a group project, I first want to

(A) have "group brainstorming" where everyone contributes ideas.

(B) trainstom individually and then come together as a group to

compare ideas.

34. I consider it higher praise to call someone

(A) intelligent.

(B) imaginative.

35. When I meet people at a birthdsy party, I am more likely to remember

(A) what they looked like.

(B) what they said about themselves.

36. When I am learning a new subject, I prefer to

(A) stay focused on that subject, learning as much about it as 1 can.

(B) try to make connections between that subject and related subjects.

37. I am more likely to be considered

(A) outgoing

(B) reserved. 


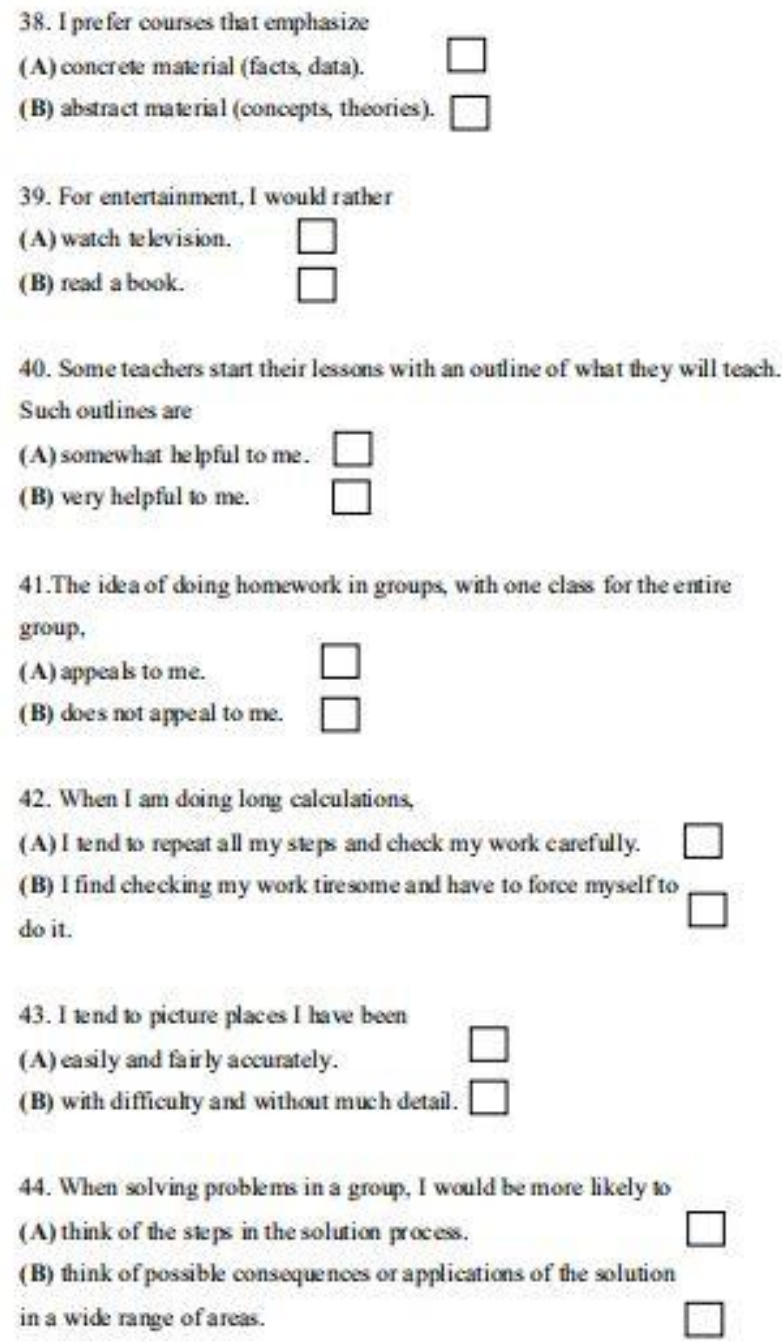

\section{Data Collection Procedure}

Creswell (2012) mentioned that ideally, there are three steps in the data collection procedure ; deciding the target population, choosing the research sample from the target population and identifying the type of data collection method that will be used. Following the first step, as mentioned above in the research participants part, since this research is an educational research, thus the target population are the primary school students in one of the SJKCs in the targeted district, Port Dickson.

The next step is deciding the research sample within the target population and to get permission from them to be studied. Welkowitz, Cohen \& Ewen (2012) as appeared in Boset, Adelina \& Nabeel (2017) stated that it is important to have a befitting sample size as it is a necessary part of the veracious measurement for the hypothesis testing .As mentioned before, the sample studied in this research arebe 30 upper primary students from one of the SJKCS located in Port Dickson.

Moving on to the final step, the identified type of data collection method for this research is survey where questionnaire has been selected as the most suitable instrument for data collection. Survey is an extremely fast, easy and cheap way of collecting data especially if a large sample is involved (Ponto 2015). The questionnaire was distributed to the participant 
DEVELOPMENT

Vol. 10, No. 3, 2021, E-ISSN: 2226-6348 @ 2021 HRMARS

via online medium,Google Form by sharing the link to them. Once the participants have completed the questionnaire, the data obtained from was analyzed using SPSS.

\section{Data Analysis}

Kveder \& Galoco (2008) stated that there are four steps in data processing: checking, editing, coding and transcribing. Data checking ensures that the data collected from the questionnaire is reliable and valid. As Chin et. al (2017) pointed out in their article, researchers are responsible to take out all invalid, incomplete or irrelevant questions or answers in questionnaire. The second step which is data editing also allows validity and reliability to be present. Data editing is a step where researchers analyse the inconsistent, unclear and incomplete answers that can be found in questionnaire (Sekaran \& Bouige 2009 as cited in Chin, Lim, Mok, Saw, \& Tey 2017) ).The third step is coding where each data collected was transferred into a comprehensible form using computer software, SPSS.The last step is transcribing where all the data from the questionnaire that have been transferred to the software was made accessible through the descriptive result based on the descriptive statistics, frequency.

\section{Findings}

Table 1 as shown below depicts the distribution of items in the questionnaire based on the four dimensions learning styles.

\begin{tabular}{|c|c|}
\hline Dimensions \& Sub-scales & Items \\
\hline $\begin{array}{l}\text { Processing } \\
\text { (Active / Reflective) }\end{array}$ & $\begin{array}{l}25,1,29,5,17 \\
37,13,9 \\
21,33,41\end{array}$ \\
\hline $\begin{array}{l}\text { Perception } \\
\text { (Sensing / Intuitive) }\end{array}$ & $38,6,18,14,2,10,34,26,22,42,30$ \\
\hline $\begin{array}{l}\text { Input } \\
\text { (Visual / Verbal) }\end{array}$ & $\begin{array}{l}7,31,23,11,15 \\
27,19,3,35,43,39\end{array}$ \\
\hline $\begin{array}{l}\text { Comprehension } \\
\text { (Sequential / Global) }\end{array}$ & $\begin{array}{l}20,36,44,8,12,32,34 \\
28,4,16,40\end{array}$ \\
\hline
\end{tabular}

Table 1: Distribution of items in the questionnaire based on the four dimensions of Felderman \& Silverman learning styles.

Table 2 shows the results from the analysis showed that in whole, the ESL upper primary school students of this SJKC are more dominant in visual (80\%) than verbal style $(20 \%)$ for input dimension; followed by sequent $(76.7 \%)$ than global style $(23.3 \%)$ for comprehension dimension; active $(56.7 \%)$ than reflective style $(43.3 \%)$ for procession dimension and intuitive (60\%) than sensing style(40\%) for perception dimension. 
Procession

\begin{tabular}{|ll|r|r|r|r|}
\hline & & & & \multicolumn{1}{c|}{$\begin{array}{c}\text { Cumulative } \\
\text { Percent }\end{array}$} \\
\hline Valid & Active & 17 & 56.7 & 56.7 & 56.7 \\
& Reflective & 13 & 43.3 & 43.3 & 100.0 \\
& Total & 30 & 100.0 & 100.0 & \\
\hline
\end{tabular}

Perception

\begin{tabular}{|ll|r|r|r|r|}
\hline & & & & \multicolumn{1}{c|}{$\begin{array}{c}\text { Cumulative } \\
\text { Percent }\end{array}$} \\
\hline Valid & Sensing & 12 & 40.0 & 40.0 & 40.0 \\
& Intuitive & 18 & 60.0 & 60.0 & 100.0 \\
& Total & 30 & 100.0 & 100.0 & \\
\hline
\end{tabular}

Input

\begin{tabular}{|rr|r|r|r|r|}
\hline & & & & \multicolumn{1}{c|}{$\begin{array}{c}\text { Cumulative } \\
\text { Percent }\end{array}$} \\
\hline Valid & Visual & 24 & 80.0 & 80.0 & 80.0 \\
& Verbal & 6 & 20.0 & 20.0 & 100.0 \\
& Total & 30 & 100.0 & 100.0 & \\
\hline
\end{tabular}

Comprehension

\begin{tabular}{|ll|r|r|r|r|}
\hline & & & & & $\begin{array}{c}\text { Cumulative } \\
\text { Percent }\end{array}$ \\
\hline Valid & Sequent & 23 & 76.7 & 76.7 & 76.7 \\
& Global & 7 & 23.3 & 23.3 & 100.0 \\
& Total & 30 & 100.0 & 100.0 & \\
\hline
\end{tabular}

Table 2: Overall distribution in learning styles dimensions for ESL upper primary students

Table 3 shows the elaborated distribution in learning styles dimensions of ESL upper primary school students.13 students(43.3\%) have strong preference towards active style compared to reflective style for procession dimension. Moreover, 16 students( $53.3 \%)$ are balanced in terms of sensing and intuitive style for perception dimension. Furthermore, 22 students (73.3\%) have strong preferences towards visual style for input dimension. Moving on to the last dimension, comprehension, 17 students (56.7\%) have a balanced preference for sequential and global style. 
Procession

\begin{tabular}{|l|l|l|l|l|}
\hline & $\begin{array}{l}\text { Frequenc } \\
\mathrm{y}\end{array}$ & Percent & $\begin{array}{l}\text { Valid } \\
\text { Percent }\end{array}$ & $\begin{array}{l}\text { Cumulative } \\
\text { Percent }\end{array}$ \\
\hline Strong/moderated & 13 & 43.3 & 43.3 & 43.3 \\
$\begin{array}{l}\text { Active } \\
\text { Balid }\end{array}$ & 11 & 36.7 & 36.7 & 80.0 \\
$\begin{array}{l}\text { Salanced } \\
\text { Strong/Moderated }\end{array}$ & 6 & 20.0 & 20.0 & 100.0 \\
Reflective & 30 & 100.0 & 100.0 & \\
Total &
\end{tabular}

\section{Perception}

\begin{tabular}{|l|l|l|l|l|}
\hline & $\begin{array}{l}\text { Frequenc } \\
y\end{array}$ & Percent & $\begin{array}{l}\text { Valid } \\
\text { Percent }\end{array}$ & $\begin{array}{l}\text { Cumulative } \\
\text { Percent }\end{array}$ \\
\hline $\begin{array}{l}\text { Strong/Moderated } \\
\text { Sensing }\end{array}$ & 8 & 26.7 & 26.7 & 26.7 \\
Valid & 16 & 53.3 & 53.3 & 80.0 \\
$\begin{array}{l}\text { Balanced } \\
\text { Strong/Moderated } \\
\text { Intuitive }\end{array}$ & 6 & 20.0 & 20.0 & 100.0 \\
Total & 30 & 100.0 & 100.0 & \\
\hline
\end{tabular}

$$
\text { Input }
$$

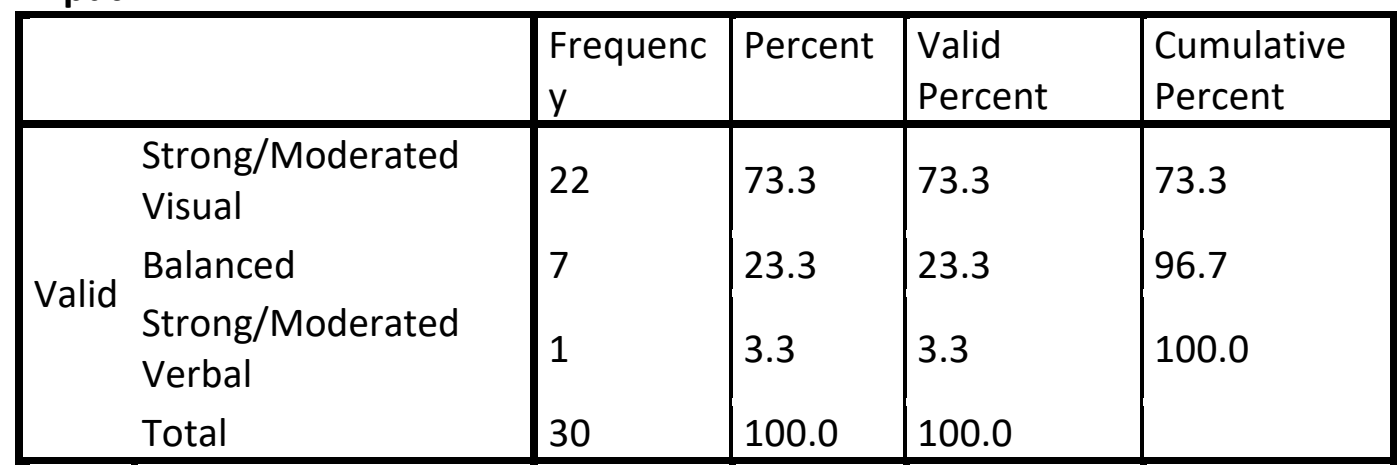

\section{Comprehension}

\begin{tabular}{|c|l|l|l|l|}
\hline & $\begin{array}{l}\text { Frequenc } \\
\mathrm{y}\end{array}$ & Percent & $\begin{array}{l}\text { Valid } \\
\text { Percent }\end{array}$ & $\begin{array}{l}\text { Cumulative } \\
\text { Percent }\end{array}$ \\
\hline $\begin{array}{l}\text { Strong/ Moderated } \\
\text { Sequent }\end{array}$ & 10 & 33.3 & 33.3 & 33.3 \\
Balanced & 17 & 56.7 & 56.7 & 90.0 \\
$\begin{array}{l}\text { Strong/Moderated } \\
\text { Global }\end{array}$ & 3 & 10.0 & 10.0 & 100.0 \\
Total & 30 & 100.0 & 100.0 & \\
\hline
\end{tabular}

Table 3: Detailed distribution in learning styles dimensions of ESL upper primary school students.

As a whole, the learning styles preferred by the ESL upper primary school students can be concluded in descending order where the students prefer visual (80\%) than verbal style $(20 \%)$ for input dimension; followed by sequent (76.7\%) than global style (23.3\%) for 
comprehension dimension; active (56.7\%) than reflective style $(43.3 \%)$ for procession dimension and intuitive (60\%) than sensing style(40\%) for perception dimension. Based on the findings, the researcher suggests a further study to be conducted to investigate the educators' specifically teachers' teaching style as having contradicting teaching styles and the learning styles will definitely deter students from achieveing avademic development as stated by (Faryadi, 2012).

\section{Conclusion \& Future Work}

To conclude, it is highly suggested that teachers especially English teacher use more visual cues such as images, illustrations, diagrams and graphsvisual in lessons as $80 \%$ of the students prefer visual style than verbal style. Besides that, English teachers should also use small additive steps that would lead the students to have a learning progress that is linear as $76.7 \%$ leans towards sequent style than global style. Furthermore, English teacher can create opportunities for innnovation to take place as $60 \%$ prefer intuitive style which means these students are more comfortable in finding innovative and new ways to solve existing and old problems. Moreover, hands-on activities in classroom and group activities are highly suggested to be conducted by the English teachers as $56.7 \%$ of the students are active learners. Researcher hopes that this paper will serve as a boost to educators out there to further upgrade their teaching strategies based on the results and suggestions that have been included in this paper.

Future work branching from this paper can be done based on the following aspects; Learning Styles Among ESL Lower Primary Students and Gender Differences In Respect to Learning Styles Among ESL Primary Students. An extension of this paper's results that were obtained from the ILS questionnaire can serve as a point of beginning for the upcoming researches.

\section{References}

Armstrong, A. M. (2004). Instructional Design in the Real World: A View from the Trenches. United States: Information Science Publishing.

Boset, S. A. A., Adelina, A., \& Nabeel, A. (2017). A conceptual analysis of the factors affecting EFL teachers' professional performance. International Journal of Language Education and Applied Linguistics (IJLEAL) 7.

Cassidy, S., \& Eachus, P. (2000). Learning Styles, academic belief systems, self-report student proficiency and acdemic achievement in higher education. Educational Psychology.

Chin, Z. D., Lim, C. Y., Mok, Y. J., Saw, Q. S., \& Tey, Y. L. (2017). Study of in-service training, job promotion, working environment and work passion on job performance among the primary schools' English teacher in Malaysia. 1-161.

Choudhary, R., Dullo, P., \&Tandon, R. V. (2011). Gender differences in learning style preferences of first year Medical students. PakJ Physiol, 7(2), 42-45.

Creswell, J. W. (1994). Research design: Qualitative and quantitative approaches.

Thousand Oaks, CA: Sage Publications, Inc.

Creswell, J. W. (2012). Educational research: Planning, conducting, and evaluating quantitative and qualitative research. (4th ed.). Boston, MA: Pearson.

Drago, W. A., \& Wagner, R. J. (2004). VARK preferred learning styles and online education. Management Research News, 27(7), 1-13.

Dunn, R. S., \& Dunn, K. J. (1978). Teaching students through their individual learning styles: A practical approach. Prentice Hall. 
DEVELOPMENT

Vol. 10, No. 3, 2021, E-ISSN: 2226-6348 @ 2021 HRMARS

Faryadi, Q. (2012). Effective Teaching and Effective Learning: Instructional Design Perspective. International Journal of Engineering Research and Applications, 2(1), 222-228.

Fazarro, D. E., Pannkuk, T., Pavelock, D., \& Hubbard, D. (2009). The effectiveness of instructional methods based on learning style preferences of agricultural students: A research tool for continuous improvement for faculty in Career and Technical Education (CTE) programs. Journal of Industrial Teacher Education, 45(3). 84-104

Felder, R. M., \& Silverman, L. K. (1988). Learning and teaching styles in engineering education. Engineering Education, 78(7), 674-681.

Felder, R. (1993). Reaching the second tier: learning and teaching styles in college science education. Journal of College Science Teaching, 23(5), 286-290.

Felder, R., \&Soloman, B. (2006).Learning styles and strategies. Retrieved from http://www.ncsu.edu/felder-public/ILSdir/styles.htm.

Felder, R., \& Spurlin, J. (2005). Applications, reliability and validity of the Index of Learning Styles. International Journal of Engineering Education, 21 (1), 103-112.

Fleming, N., \& Baume, D. (2006). Learning styles again: varking up the right tree!, Educational Developments. SEDA Ltd, issue 7.4 Nov , 4-7.

Graf, S., Viola, S. R., Leo, T., \& Kinshuk. (2007). In-depth analysis of the Felder-Silverman learning style dimensions. Journal of Research on Technology in Education, 40(1).

Gregorc, A. (1982). Learning style/brain research: Harbinger of an emerging psychology. Student learning styles and behaviour. Reston: National Association of Secondary School Principals.

Jantan, R., \& Razali, M. (2002). Psikologi Pendidikan Pendekatan Kontemporari. Kuala Lumpur: McGraw Hill Education

Kang, S. (1999). Learning styles: Implications for ESL/EFL instruction. English Teaching Forum, 37(4), 6.

Kolb, D. A. (1976). The Learning Style Inventory: Technical Manual, Boston, Ma.: McBer.

Kolb, D. A. (1984). Experiential learning: Experience as the source of learning and development. New Jersey: Prentice-Hall Inc.

Lau, W. W. F., \& Yuen, A. H. K. (2010). Gender differences in learning styles: Nurturing a gender and style sensitive computer science classroom. Australasian Journal of Educational Technology. 26(7), 1090-1103.

MacDonald, G., \& Headlam. (2014). Inteoduction to Research Methods.Community College Review, 33(1), 22-37

McCarthy, B. (1982). The 4Mat System. Arlington Heights, Ill.: Excel Publishing Co.

Mok S. S. (2003). IImu Pendidikan Untuk KPLI: Psikologi Pendidikan \& Pedagogi. Jaya Subang. Kumpulan Budiman Sdn. Bhd.

Murphy, R. J., Gray, S. A., Straja, S. R., \& Bogert, M. C. (2004). Student learning preferences and teaching implications. :Educational methodologies. Journal of Dental Education, 68 (8), 859-866.

Omair, A. (2014). Sample size estimation and sampling techniques for selecting a representative sample. Journal of Health Specialties, 2(4), 142-147.

Pashler, H., McDaniel, M., Rohrer, D., \& Bjork, R. (2008). Learning styles concepts and evidence. Psychological science in the public interest, 9(3), 105-119.

Putintseva, T. (2006). The importance of learning styles in ESL/EFL. The Internet TESL Journal, 12(3) 
INTERNATIONAL JOURNAL OF ACADEMIC RESEARCH IN PROGRESSIVE EDUCATION AND

DEVELOPMENT

Vol. 10, No. 3, 2021, E-ISSN: 2226-6348 @ 2021 HRMARS

Sangeeth. (2014). Learning styles concepts and evidence. Psychological science in the public interest, 9(3), 105-119

Thronson, R. M. (1984). Achievement as a function of learning style preference in beginning computer programming courses (Doctoral dissertation, Montana State University).

Thelen, H. (1954). Dynamics of groups at work. Chicago: University of Chicago Press.

Tong, B., \& Marcia, C. (2010). Models of teaching. Boston, MA: Pearson/Allyn and Bacon.

Wu, D. C. (2014). Learning styles, subject matter, and effectiveness in undergraduate distance education (Doctoral dissertation, Liberty University) 